\title{
Cytogenetics of Spindle Cell/Pleomorphic Lipomas: Karyotyping and FISH Analysis of 31 Tumors
}

\author{
IOANNIS PANAGOPOULOS ${ }^{1}$, LUDMILA GORUNOVA ${ }^{1}$, MARIUS LUND-IVERSEN ${ }^{2}$, KRISTIN ANDERSEN $^{1}$, \\ HEGE KILEN ANDERSEN ${ }^{1}$, INGVILD LOBMAIER ${ }^{2}$, BODIL BJERKEHAGEN ${ }^{2}$ and SVERRE HEIM ${ }^{1,3}$ \\ ${ }^{1}$ Section for Cancer Cytogenetics, Institute for Cancer Genetics and Informatics, \\ The Norwegian Radium Hospital, Oslo University Hospital, Oslo, Norway; \\ ${ }^{2}$ Department of Pathology, The Norwegian Radium Hospital, Oslo University Hospital, Oslo, Norway; \\ ${ }^{3}$ Institute of Clinical Medicine, Faculty of Medicine, University of Oslo, Oslo, Norway
}

\begin{abstract}
Background: Spindle cell/pleomorphic lipomas are benign tumors. Here, we present our cytogenetic data on 31 such tumors. Materials and Methods: G-banding chromosome analysis and (in selected cases) fluorescence in situ hybridization (FISH) using probes for FOXO1, RBI, and HMGA2 were performed. Results: Rearrangements of chromosome 13 were found in $58 \%$ of tumors. Chromosomes $6,1,12$, and 11 were also involved in $42 \%, 26 \%, 26 \%$, and $23 \%$ of tumors, respectively. FISH analysis showed heterozygous deletion of RBI in seven samples with chromosome 13 aberrations. In four of them, FOXO1 was also deleted. In two tumors with 12 q15 rearrangements, FISH confirmed that HMGA2 was targeted. Conclusion: Structural rearrangements of $13 q$ or losses of an entire chromosome 13 are the most common cytogenetic aberrations in spindle cell/pleomorphic lipomas. However, cytogenetic variation exists similarly to what is found in other lipomas, suggesting that various pathways may be responsible for tumorigenesis.
\end{abstract}

Spindle cell lipoma was first described by Enzinger and Harvey in 1975 (1) as a benign tumor usually occurring subcutaneously in the upper back, shoulder or posterior neck of middle-aged men, after which several other studies

This article is freely accessible online.

Correspondence to: Ioannis Panagopoulos, Section for Cancer Cytogenetics, Institute for Cancer Genetics and Informatics, The Norwegian Radium Hospital, Oslo University Hospital, Montebello, PO Box 4954 Nydalen, NO-0424 Oslo, Norway. Tel: +47 22782362, e-mail: ioannis.panagopoulos@rr-research.no

Key Words: Spindle cell lipomas, pleomorphic lipomas, cytogenetics, chromosome 13, chromosome 12, RB1 gene, FOXO1 gene, HMGA2 gene. confirmed the existence of this lipoma subgroup (2-9). Their occurrence has also been reported in other sites such as the face, limbs, oral cavity, larynx, bronchus, orbit, breast, perianal region, and spermatic cord (10). Macroscopically, spindle cell lipomas are mostly well circumscribed, round or discoid nodules. Histologically, they consist of a mixture of bland spindle cells and mature adipocytes. The matrix surrounding the cells is composed of varying amounts of mucoid material and collagen bundles haphazardly distributed throughout the lesion $(1,2,4,6)$. Spindle cell lipomas can be challenging to the radiologist, pathologist, or surgeon to diagnose, particularly when they contain little internal fat (8).

Pleomorphic lipomas were first described by Shmookler and Enzinger (11). Like spindle cell lipomas, their most common location is in subcutaneous tissue of the shoulders and posterior neck of adults, especially men. They are solitary, circumscribed, slow-growing, painless tumors. Microscopically, they show admixture of mature adipose tissue and pleomorphic multinucleated cells, so-called florette cells, and overall display histological and immunophenotypic features similar to those of spindle cell lipomas $(3,4,12)$. Thus, this tumor type is now accepted as an extremely pleomorphic variant of spindle cell lipomas and the two are lumped together as spindle cell/pleomorphic lipoma (13).

In 1994, Mandahl et al. (14) reported the cytogenetic findings in six spindle cell lipomas and two pleomorphic lipomas. One spindle cell lipoma had a supernumerary ring chromosome as the sole anomaly. The other five spindle cell lipomas and both pleomorphic lipomas had hypodiploid stemlines with monosomy 16 or unbalanced aberrations leading to loss of 16q13-qter. Unbalanced aberrations of chromosomes 13 and 10 were also found. In addition, both pleomorphic lipomas, but none of the spindle cell lipomas, had hypotetraploid sidelines, multiple nonclonal aberrations, and telomeric associations (14). 
Table I. Clinicopathological and cytogenetic data of the 31 spindle cell/pleomorphic lipomas.

\begin{tabular}{ccccc}
\hline $\begin{array}{c}\text { Case Gender/ Location } \\
\text { Age }\end{array}$ & Depth & $\begin{array}{c}\text { Largest } \\
\text { diameter } \\
(\mathrm{cm})\end{array}$ & Diagnosis & $\begin{array}{c}\text { Material for } \\
\text { cytogenetic } \\
\text { analysis }\end{array}$ \\
\end{tabular}

\begin{tabular}{ccccccc}
\hline 1 & M/46 & Upper arm & Subcutaneous & 5 & Spindle cell lipoma & Resection \\
2 & M/58 & Neck & Not available & 6.5 & Spindle cell lipoma & Resection \\
3 & M/59 & Knee & Subcutaneous & 1 & Spindle cell lipoma & Resection \\
4 & M/66 & Thenar & Intramuscular & 3 & Spindle cell lipoma & Resection \\
5 & F/62 & Back & Subcutaneous & 8.5 & Pleomorphic lipoma & Resection
\end{tabular}

38 46,XY,-10,der(11)add(11)(p15)add(11)(q21),inc [cp14]
$45, \mathrm{XY}, \operatorname{del}(2)(\mathrm{q} 33), \operatorname{del}(6)(\mathrm{q} 15), \operatorname{inv}(11)(\mathrm{p} 15 \mathrm{q} 23),-13[\mathrm{cp} 15]$
$45 \sim 46, \mathrm{XY}, \operatorname{del}(1)(\mathrm{p} 32), \operatorname{add}(2)(\mathrm{p} 25), \operatorname{inc}[\mathrm{cp} 4]$
$46, \mathrm{XY}, \mathrm{t}(13 ; 14)(\mathrm{q} 12 ; \mathrm{q} 24)[15]$ $45 \sim 46, \mathrm{XX}, \operatorname{del}(2)(\mathrm{q} 11), \operatorname{der}(2) \mathrm{t}(2 ; 13)(? ; \mathrm{q} 14), \operatorname{del}(6)$ (q13q23), del(13)(q21),der(?13)t(8;?13)(p11;q11), der(17)(17qter->17q21::17p13->17q21::8q11

->8qter)[cp6]/44 45, idem,-X[cp5]/86 95, idemx2[cp5] $57 \sim 59<2 \mathrm{n}>, \mathrm{XY},+\mathrm{X},+5,+8,+12,+\operatorname{der}(12) \mathrm{t}(12 ; 17)$

$(\mathrm{q} 15 ; \mathrm{q} 23),+15,+18+18,+20,+21+21,+\operatorname{mar}[\mathrm{cp} 11]$ $46, X Y, t(16 ; 19)(q 13 ; \mathrm{p} 13)[16] / 46, \mathrm{XY}, \operatorname{del}(1)$

$$
\text { (q32),inc[2]/46,XY[2] }
$$$$
45, \mathrm{XY},-13,-22,+\operatorname{mar}[\mathrm{cp} 6]
$$

42 46,XY,add(5)(p15), del(7)(q22),

$\operatorname{del}(10)(q 22), \operatorname{add}(19)(q 13)[\mathrm{cp} 6] / 46, X Y[8]$

44,Y,t(X;14)(p22;q13),der(1)t(1;18)(p13;q11), $-6,-9, \operatorname{der}(10) \mathrm{t}(6 ; 10)(\mathrm{p} 11 ; \mathrm{p} 11), \mathrm{t}(11 ; 17)$ (p11;p13),der(13)t(1;13)(p13;q14)ins $(13 ; ?)(\mathrm{q} 14 ; ?), \operatorname{add}(18)(\mathrm{q} 11)[15]$ $45, X Y,-3, \operatorname{der}(6) \mathrm{t}(3 ; 6)(\mathrm{q} 12 ; \mathrm{q} 13), \operatorname{del}(13)(\mathrm{q} 14 \mathrm{q} 22)[15]$ $46, X Y, t(1 ; 12)(p 32 ; q 15)[15]$

$45, \mathrm{XY},-6, \operatorname{der}(13) \mathrm{t}(6 ; 13)(\mathrm{q} 13 ; \mathrm{q} 14), \operatorname{der}(14)$ $\mathrm{t}(6 ; 14)(\mathrm{p} 21 ; \mathrm{q} 32)[\mathrm{cp} 8] / 46, \mathrm{XY}[2]$

$46, \mathrm{XY}, \mathrm{t}(1 ; 13)(\mathrm{p} 36 ; \mathrm{q} 22), \operatorname{der}(4) \mathrm{t}(4 ; 6)(\mathrm{q} 21 ; \mathrm{q} 21)$, $\operatorname{der}(6) \operatorname{del}(6)(\mathrm{p} 21) \mathrm{t}(4 ; 6), \mathrm{t}(15 ; 22)(\mathrm{q} 21 ; \mathrm{q} 12)[14] / 46, \mathrm{XY}[2]$ $46, \mathrm{XX}, \mathrm{t}(1 ; 7 ; 5)(\mathrm{p} 36 ; \mathrm{p} 15 ; \mathrm{q} 11)[9] / 46, \mathrm{XX}[16]$ 46,XY,der(1)t(1;12)(q23;q15),der(12)t(1;12) $(\mathrm{q} 23 ; \mathrm{q} 11),-13,-21,+2 \operatorname{mar}[17]$ $46, X X, t(12 ; 14)(\mathrm{q} 15 ; \mathrm{q} 24)[15]$ $48 \sim 49, \mathrm{XY},+8,+8,+12[\mathrm{cp} 5] / 46, \mathrm{XY}[4]$

$46, \mathrm{XY}, \mathrm{t}(5 ; 13)(\mathrm{p} 15 ; \mathrm{q} 14)[22]$ 46,XY,t(5;13)(p15;q14)[5]/46,XY[2]

46,X,inv $(X)(\mathrm{p} 22 \mathrm{q} 26), \operatorname{der}(4) \mathrm{t}(4 ; 11)(\mathrm{p} 16 ; \mathrm{q} 22)$, $\operatorname{del}(10)(\mathrm{p} 13), \mathrm{t}(12 ; 12)(\mathrm{q} 15 ; \mathrm{q} 21)[12] / 47$, idem,+10 [cp3] 46,X,t(X;22)(p21 22; q11), del(13)(q14)[15]

$47, X Y,+4,-6,+8, \operatorname{der}(12) \operatorname{del}(12)(\mathrm{q} 14 \mathrm{q} 14) \operatorname{inv}(12)$

(q12q14),-13,-14,-16,+18,+2mar[14]/46,XY[2] $46, X Y, t(7 ; 17)(\mathrm{q} 22 ; \mathrm{p} 13)[3] / 46, \mathrm{XY}[10]$ $69, \mathrm{XXY},+\mathrm{Y},-6,-8,-10,-13,+15,-16,+18,+19$, $+20,+21,-22[11] / 46, X Y[2]$ $65 \sim 72, \mathrm{XXY},-1, \mathrm{i}(11)(\mathrm{q} 10)$, ins $(12 ; ?)(\mathrm{q} 13 ; ?) \times 2$, $\operatorname{add}(15)(\mathrm{p} 13), \operatorname{add}(17)(\mathrm{p} 13) \times 2, \operatorname{add}(19)(\mathrm{p} 13)$, $\operatorname{add}(19)(\mathrm{p} 13), \operatorname{add}(21)(\mathrm{p} 11), \operatorname{der}(22) \mathrm{t}$ $(1 ; 22)(\mathrm{p} 13 ; \mathrm{q} 13),+1 \sim 2 \mathrm{r}$, inc [cp7]/46,XY[2]

Resection Resection

Resection Resection

Resection
$45, \mathrm{XY},-13,-14,+\operatorname{mar}[10]$
$44 \sim 45, \mathrm{XY}, \operatorname{add}(6)(\mathrm{q} 23),-10,-13, \operatorname{der}(16) \mathrm{t}(10 ; 16)(\mathrm{q} 11 ; \mathrm{q} 13)$, $+\operatorname{mar}[\mathrm{cp} 5] / 44 \sim 45$, idem, $\operatorname{del}(11)(\mathrm{q} 23)[\mathrm{cp} 5]$ $45, \mathrm{XY},-6, \operatorname{der}(13) \mathrm{t}(6 ; 13)(\mathrm{p} 21 ; \mathrm{q} 14)[10]$ $46, X Y, \operatorname{der}(6) \mathrm{t}(6 ; 11)(\mathrm{p} 21 ; \mathrm{q} 13), \operatorname{der}(8) \mathrm{t}(6 ; 8)(\mathrm{p} 21 ; \mathrm{p} 21)$, $\operatorname{der}(11) \mathrm{t}(8 ; 11)(\mathrm{p} 21 ; \mathrm{p} 15) \operatorname{del}(11)(\mathrm{q} 13)[11]$ 47,XY,del(13)(q11q14),der(16)add(16)(p11) $\operatorname{del}(16)(\mathrm{q} 22), \operatorname{add}(17)(\mathrm{p} 13), \operatorname{der}(17) \mathrm{t}(17 ; 18)$ (q23; q12), add(18)(q12),+r[2]/ 45 46,idem, -2 [cp6]/46,XY[7]


Table I. Continued

\begin{tabular}{|c|c|c|c|c|c|c|c|}
\hline Case & $\begin{array}{l}\text { Gender/ } \\
\text { Age }\end{array}$ & Location & Depth & $\begin{array}{l}\text { Largest } \\
\text { diameter } \\
(\mathrm{cm})\end{array}$ & Diagnosis & $\begin{array}{l}\text { Material for } \\
\text { cytogenetic } \\
\text { analysis }\end{array}$ & Karyotype \\
\hline 30 & $\mathrm{~F} / 53$ & Neck & Not available & 4.2 & Spindle cell lipoma & Resection & $\begin{array}{l}\text { 46,XX,der(4)inv(4)(p14q31)t(4;6)(q31;p21),t(5;21) } \\
(\mathrm{q} 33 ; \mathrm{q} 22), \operatorname{der}(6) \mathrm{t}(4 ; 6)(\mathrm{p} 14 ; \mathrm{p} 21), \operatorname{del}(13)(\mathrm{q} 12 \mathrm{q} 22)[10]\end{array}$ \\
\hline 31 & $\mathrm{~F} / 63$ & Neck & Not available & 7 & Spindle cell lipoma & Resection & $45, \mathrm{XX},-6, \operatorname{der}(22) \mathrm{t}(6 ; 22)(\mathrm{p} 21 ; \mathrm{q} 13)[5] / 46$, idem,$+\operatorname{mar}[7]$ \\
\hline
\end{tabular}

Current cytogenetic knowledge about these tumors is scant. According to the Mitelman Database of Chromosome Aberrations and Gene Fusions in Cancer (http://cgap. nci.nih.gov/Chromosomes/Mitelman, Database last updated on August 23, 2017), only 28 spindle cell/pleomorphic lipomas (only two of them were pleomorphic) with abnormal karyotypes have been reported in seven English-language articles (14-20). In addition, another two cases of spindle cell lipoma were reported in a French-language report (21). By way of comparison, the same database contains information on altogether 490 karyotypically abnormal ordinary lipomas reported in 57 articles. The cytogenetic knowledge about spindle cell/pleomorphic lipomas based on these reports can be summarized as follows: in the majority of cases, the chromosome number is 44-46 and monosomies or partial chromosome losses are the dominating abnormalities. Chromosomes 13 and 16 are the most frequently affected with monosomy for or partial loss of chromosome 13 and deletion of 16q13-qter coming across as the most common aberrations (22). We wanted to add to the cytogenetic knowledge on spindle cell/pleomorphic lipoma and for this reason present our data on another 31 tumors of this type.

\section{Materials and Methods}

Materials. Information about the patients' sex and age and the tumors' location, depth, and size is given in Table I. The patients were 25 males and 6 females. The age range was from 32 to 80 years, with a median of 58 . In 26 patients, the diagnosis was spindle cell lipoma (Figure 1A), in one of them with a myxoid component, whereas the diagnosis was pleomorphic lipoma in 5 tumors (Figure 1B). Eleven of the tumors were located in the neck, five in the back, three in the shoulders, two in the thoracic wall, and two in the upper arm. Other tumors were found in the leg, flank, instep, knee, wrist, hand, and scalp.

The material for cytogenetic analysis consisted of 26 tumor resections and 7 tumor biopsies from 31 patients ( 2 tumors were examined first on biopsy material, later on resectates). They were diagnosed as spindle cell or pleomorphic lipoma at the Department of Pathology and cytogenetically analyzed at the Section for Cancer Cytogenetics, both at The Norwegian Radium Hospital, Oslo University Hospital, between 2002 and 2016. The study was approved by the regional ethics committee (Regional komité for medisinsk forskningsetikk Sør-Øst, Norge, http://helseforskning.etikkom.no). All patient information has been de-identified.

G-banding and karyotyping. Fresh tissues from a representative area of resected tumors $(n=26)$ or core needle biopsies $(n=7$; two tumors were examined both as biopsies and resectates) were received and analyzed cytogenetically as part of our diagnostic routine. The samples were disaggregated mechanically and enzymatically with collagenase II (Worthington, Freehold, NJ, USA). The resulting cells were cultured and harvested using standard techniques (23). Chromosome preparations were G-banded with Wright's stain (Sigma-Aldrich; St. Louis, MO, USA) and examined. Metaphases were analyzed and karyograms were prepared using the CytoVision computer assisted karyotyping system (Leica Biosystems, Newcastle, UK). The karyotypes were described according to the International System for Human Cytogenomic Nomenclature (24).

Fluorescence in situ hybridization (FISH). The following probes were used for FISH analysis: i) FOXO1 break apart rearrangement probe purchased from Cytocell (Cytocell, Cambridge, UK). This probe hybridizes to a $1.5 \mathrm{Mbp}$ sequence on $13 \mathrm{q} 14.11$ which contains the FOXO1 gene. According to the company's information, it consists of two probes $(405 \mathrm{~kb}$ and $183 \mathrm{~kb})$, labelled in green, situated proximal to the FOXO1 gene and covering markers D13S765 and SHGC-111293, and four probes (123 kb, $142 \mathrm{~kb}$, $95 \mathrm{~kb}$, and $253 \mathrm{~kb}$ ), labelled in red, situated distal to the FOXO1 gene and covering markers D13S638 and SHGC-16596. ii) RB1 deletion probe, purchased from Cytocell (Cytocell, Cambridge, UK) and used to detect deletion of the $R B 1$ locus in 13q14.2. It consists of a $318 \mathrm{~kb}$ red probe spanning $R B 1$ and a 13 qter green probe acting as a control for chromosome 13. iii) A homemade break apart $H M G A 2$ probe (25). The 5'-end of the probe (red signal) was constructed from a pool of the clones RP11-185K16, RP11-30I11, and RP11$662 \mathrm{G} 15$. The 3'-end of the probe (green signal) was constructed from a pool of the clones RP118B13, RP11-745O10, and RP11263A04. All of them map to chromosome subband $12 \mathrm{q} 14.3$ and cover the HMGA2 locus. Detailed information on the HMGA2 BAC clones is given elsewhere (25). Fluorescent signals were captured and analyzed using the CytoVision system (Leica Biosystems, Newcastle, UK).

\section{Results}

Karyotyping. All the samples had cells carrying cytogenetic aberrations; during the same time period, only one other tumor with this diagnosis was subjected to cytogenetic 
analysis but was found to have a normal karyotype (data not shown). Most of the tumors had pseudo- or near-diploid karyotypes, although two were near-triploid (cases 23 and 24) (Table I). In two tumors (cases 17 and 23), only numerical changes were found whereas the rest had structural only or both structural and numerical aberrations. In cases 9 and 18, cytogenetic analysis was performed on both a tumor biopsy (a) and material from the resected tumor (b). In case 9, cytogenetically-different structural aberrations were found in the biopsy and the resection (Table I, 9a and $9 b)$, whereas the two samples in case 18 had the same karyotypes (Table I, 18a and 18b).

The most frequent aberrations (over 20\%) involved numerical and/or structural changes of chromosomes 13, 6, 1, 12 , and 11 (in decreasing order; Table I). Abnormalities of chromosome 13 were found in 18 tumors $(58 \%)$. Loss of the entire chromosome (cases 2, 8, 15, 21, 23, 25, and 26) or partial losses of the long arm (cases 5, 9b, 10, 12, 20, 27, 29, and 30) occurred in 15 tumors, whereas balanced translocations were seen in 3 cases $(4,13,18 \mathrm{a}$, and 18b). Partial karyotypes, showing the rearrangements of chromosome 13 , for samples 9b, 12, 18b are presented in Figure 2.

Changes of chromosome 6 were found in 13 tumors $(42 \%)$. Seven of them had either loss of the entire copy (cases 21 and 23) or deletions in or of 6q (cases 2, 5, 9b, 10, 12,26 , and 27), while 6 tumors had structural aberrations targeting 6p21 (cases 12, 13, 27, 28, 30, and 31).

Chromosome 1 aberrations were seen in 8 tumors (26\%), either as losses in the p-arm (case 3) or q-arm (cases 7 and 24) or as balanced rearrangements (cases $9 \mathrm{~b}, 11$, and 13-15). Changes of chromosome 12 were also found in 8 tumors; in the majority of them (cases $6,11,15,16,19,21$, and 24), structural aberrations affected region 12q13 15, whereas 2 tumors (cases 6 and 17) had an extra copy of the chromosome. The partial karyotype showing the $\mathrm{t}(1 ; 12)(\mathrm{p} 32 ; \mathrm{q} 15)$ for sample 1 is presented in Figure 2. The arms of chromosome 11 were affected by structural aberrations in a total of 7 tumors (23\%) (cases 1, 2, 9b, 19, 24, 26, and 28).

FISH. The results of interphase FISH analyses with $R B 1$ (13q14.2), 13qter, FOXO1 (13q14.11), and HMGA2 (12q14) probes are presented in Table II. The analyses could be performed on 13 samples (12 cases): eight cases with chromosome 13q aberrations (4, 9b, 12, 18a, 18b, 27, 29, and 30 ), one tumor with chromosome 13 and $12 \mathrm{q}$ changes (case 15), one tumor with 12q rearrangement (case 11), and three cases without aberrations of chromosomes 12 and 13 (14, 22, and 28).

Heterozygous deletion of the $R B 1$ probe was observed in seven cases: 9b, 12, 18a and 18b, 27, 29, and 30. In cases 9b and 27 , heterozygous deletion of the 13qter probe was also found. Furthermore, in cases 9b, 12, 29, and 30, heterozygous deletion of FOXOI was observed; in case 29,
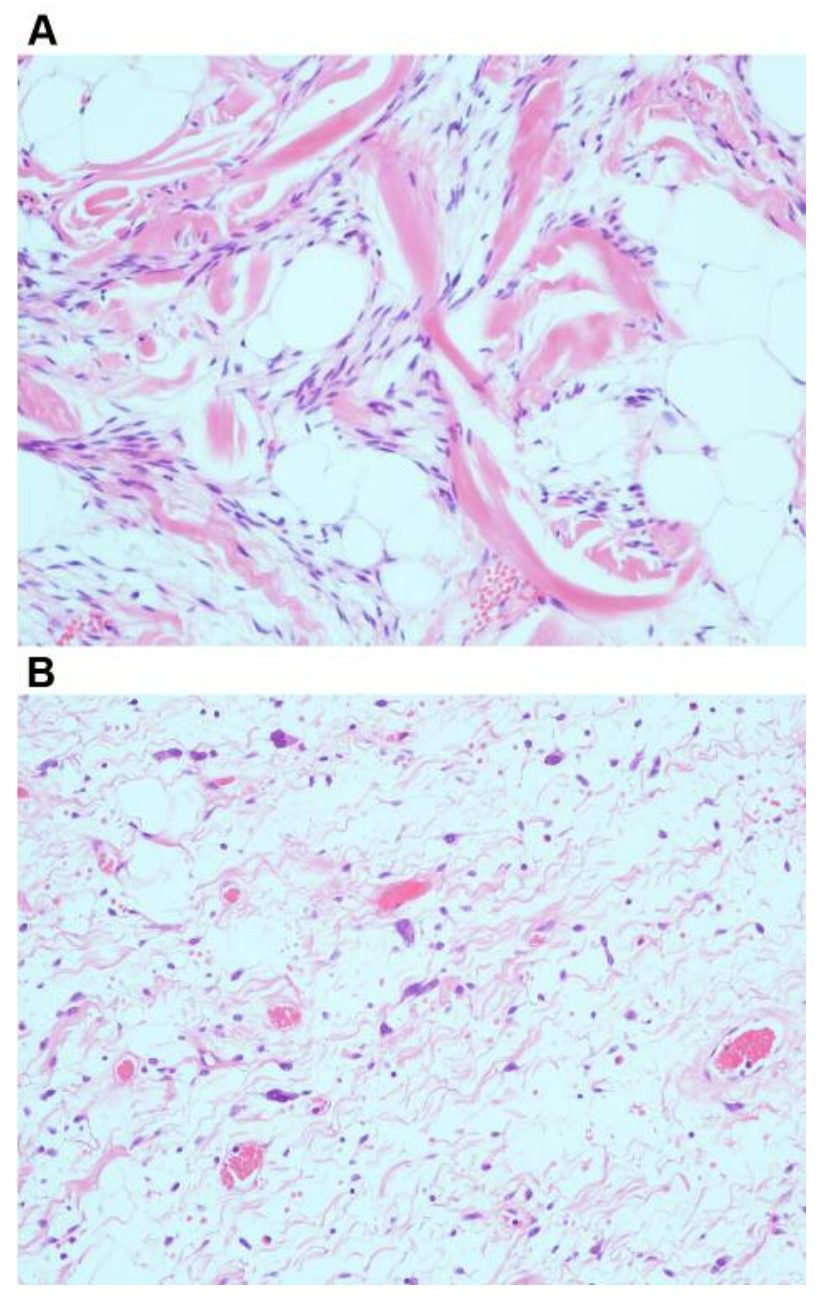

Figure 1. Histological examination of spindle cell and pleomorphic lipomas. A) Typical features of spindle cell lipoma with admixed ropy collagen, bland spindle cells, and elements of mature fat. B) Typical features of pleomorphic lipoma with easily identifiable large atypical cells with hyperchromatic nuclei, admixed with bland spindle cells, collagen, and mature adipocytes. Hematoxylin and eosin $(H \& E)$ staining, magnification $\times 200$ ).

the deletion was partial. In contrast, cases $18 \mathrm{a}$ and $18 \mathrm{~b}$ did not show deletions of FOXO1. Rearrangements of the $H M G A 2$ gene were detected in cases 11 and 15. Cases 4, 14, 22 , and 28 did not show any changes by FISH with the probes used. In Figure 2 FISH analyses are shown with $F O X O 1$ break apart and $R B 1$ deletion probes for samples $9 \mathrm{~b}$, 12 , and $18 \mathrm{~b}$, and with an $H M G A 2$ probe for sample 11.

\section{Discussion}

To the best of our knowledge, the present study describes the largest series of cytogenetically-abnormal spindle cell/ pleomorphic lipomas. Our findings show that structural 


\section{Sample 9b}
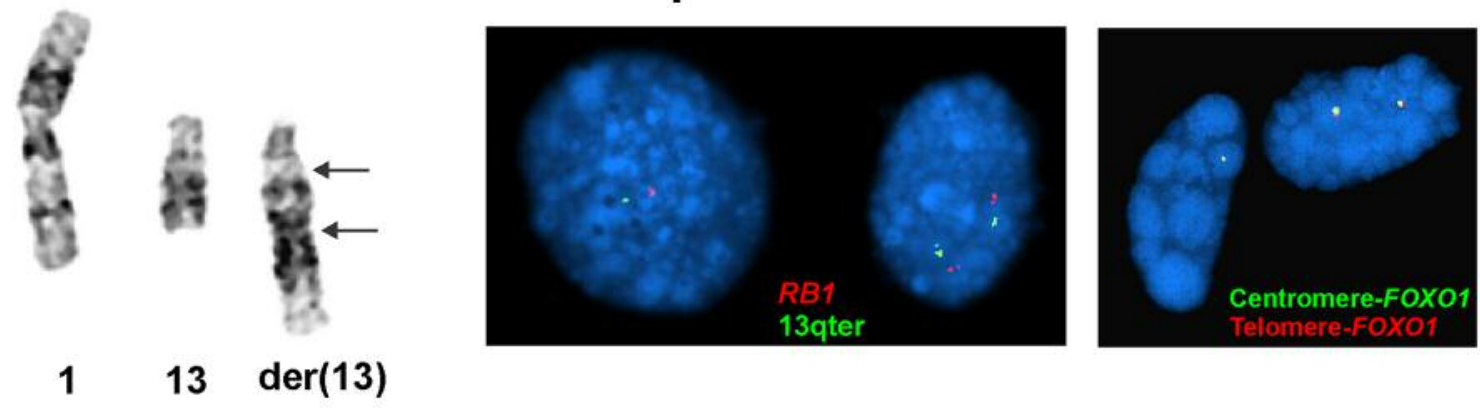

\section{Sample 12}
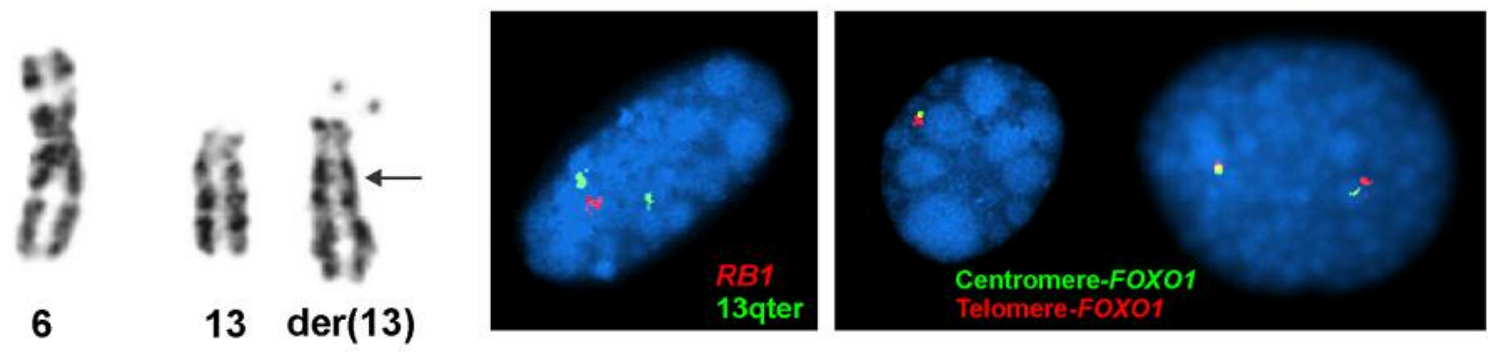

Sample 18b
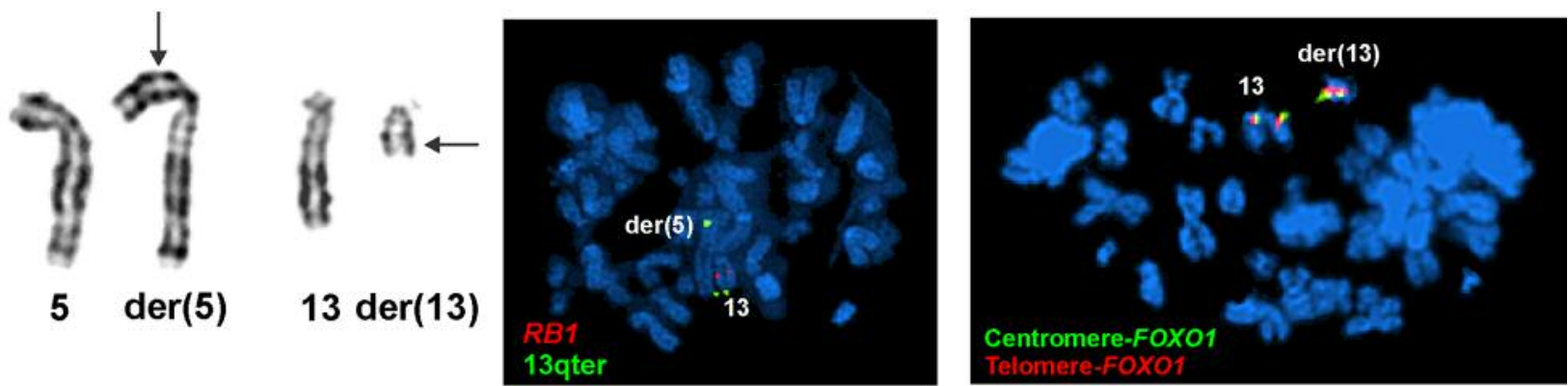

\section{Sample 11}
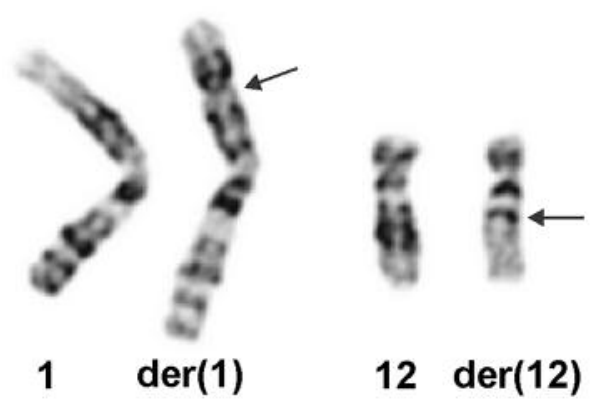

$12 \operatorname{der}(12)$

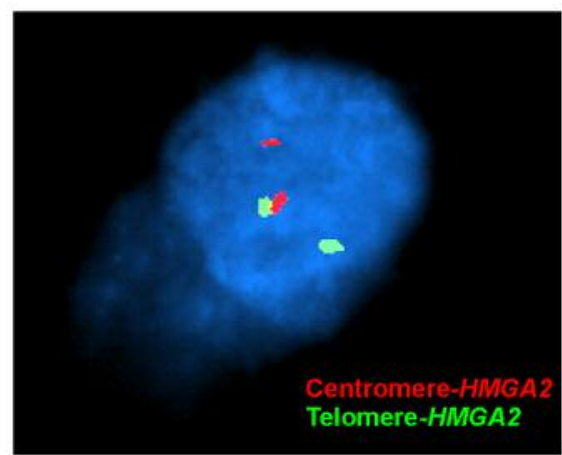

Figure 2. Cytogenetic and FISH analyses of spindle cell/pleomorphic lipomas. Results for samples 9b, 12, 18b, and 11 are shown. Left: partial karyotype. Arrows indicate breakpoints. Right: FISH analyses with FOXO1 break apart and RB1 deletion probes for samples $9 b, 12$, and18b, and with an HMGA2 probe for sample 11. 
Table II. Summary of FISH analyses of 13 samples of spindle cell/pleomorphic lipoma.

\begin{tabular}{|c|c|c|c|c|c|c|c|}
\hline \multirow[t]{2}{*}{ Case } & \multicolumn{2}{|c|}{$\begin{array}{c}\text { Heterozygous } \\
\text { deletion of }\end{array}$} & \multirow{2}{*}{$\begin{array}{l}\text { No of } \\
\text { nuclei } \\
\text { studied }\end{array}$} & \multirow{2}{*}{$\begin{array}{c}\text { Heterozygous } \\
\text { deletion of } \\
\text { FOXO1 }(\%)\end{array}$} & \multirow{2}{*}{$\begin{array}{l}\text { No of } \\
\text { nuclei } \\
\text { studied }\end{array}$} & \multirow{2}{*}{$\begin{array}{c}\text { Rearrangement } \\
\text { of } H M G A 2 \\
(\%)\end{array}$} & \multirow{2}{*}{$\begin{array}{l}\text { No of } \\
\text { nuclei } \\
\text { studied }\end{array}$} \\
\hline & $R B 1(\%)$ & 13 qter $(\%)$ & & & & & \\
\hline 4 & 0 & 0 & 50 & fail & fail & 0 & 100 \\
\hline $9 b$ & 93 & 93 & 107 & 96 & 104 & 0 & 100 \\
\hline 11 & 0 & 0 & 100 & 0 & 100 & 100 & 100 \\
\hline 12 & 87 & 0 & 94 & 31 & 103 & 0 & 75 \\
\hline 14 & 0 & 0 & 100 & 0 & 100 & 0 & 100 \\
\hline 15 & 0 & 0 & 100 & 0 & 107 & 50 & 200 \\
\hline $18 \mathrm{a}$ & 100 & 0 & 100 & 0 & 100 & 0 & 70 \\
\hline $18 \mathrm{~b}$ & 100 & 0 & 100 & 0 & 100 & 0 & 90 \\
\hline 22 & 0 & 0 & 50 & 0 & 30 & Fail & Fail \\
\hline 27 & 96 & 96 & 99 & Not done & Not done & Not done & Not done \\
\hline 28 & 0 & 0 & 96 & Not done & Not done & Not done & Not done \\
\hline 29 & 82 & 0 & 114 & (partial) 83 & 104 & Not done & Not done \\
\hline 30 & 98 & 0 & 203 & 98 & 205 & Not done & Not done \\
\hline
\end{tabular}

aberrations, mainly deletions, of chromosome arm $13 \mathrm{q}$ or loss of the entire chromosome 13 are frequent in this tumor type inasmuch as they were found in $58 \%$ (18/31) of the tumors. This aspect of our data is in agreement with previously published reports in which deletion of $13 q /-13$ was also found in spindle cell lipomas $(14,16-18,20,21$, 26). Mandahl et al. (14) reported unbalanced aberrations leading to partial $13 q$-loss in 5 out of 8 examined spindle cell/pleomorphic lipomas (14). Dahlén et al. (17) presented 11 spindle cell lipomas with deletions of chromosome arm $13 \mathrm{q}$ or losses of the whole chromosome. In two articles, Bartuma et al. $(16,26)$ presented altogether 16 spindle cell lipomas, all of which had changes of chromosome 13. Dumollard et al. (21) reported two cases of spindle cell lipomas with chromosome 13 abnormalities. Dal Cin et al. (18) reported one spindle cell lipoma with loss of chromosome 13 and a second with 13q deletion. Finally, Welther et al. (20) reported a spindle cell lipoma with structural rearrangement of $13 \mathrm{q}$.

Deletions of $13 q$ or loss of chromosome 13 were also reported in ordinary lipomas with karyotypic aberrations, albeit less frequently $(16,17,27,28)$. In the Mitelman Database of Chromosome Aberrations and Gene Fusions in Cancer, 12 lipomas with -13 and 35 lipomas with del(13q) are listed (29). Involvement of chromosome 13 was also found in cellular angiofibroma, extramammary myofibroblastoma, and recently in angiolipoma (30-32). The morphologic similarities among cellular angiofibroma, extramammary myofibroblastoma, and spindle cell lipoma together with their cytogenetic similarities, in particular loss of material from the long arm of chromosome 13, suggest that these tumors arise through largely identical pathogenetic mechanisms from a common connective tissue precursor cell which then undergoes (myo)fibroblastic or adipocytic differentiation $(30,31,33,34)$.

The results of interphase FISH analysis with $R B 1$ and/or FOXO1 probes were in good overall agreement with the results of G-banding analysis (Tables I and II). In four tumors without chromosome 13 changes (cases 11, 14, 22, and 28), no deletions of any probe were found. Neither was deletion of $R B 1$ nor deletion of 13 qter detected in case 4 which had a balanced $\mathrm{t}(13 ; 14)$ involving $13 \mathrm{q} 12$. On the other hand, heterozygous deletion of the $R B 1$ locus was observed in seven samples with $13 \mathrm{q}$ rearrangements or loss detected by Gbanding (cases 9b, 12, 18a, 18b, 27, 29, and 30); in five of these cases, the 13qter probe was retained. In the four cases (9b, 12, 29, and 30) with structural unbalanced aberrations involving $13 \mathrm{q} 14$, both $R B 1$ and FOXO1 were deleted.

In the two samples of case 18 , with a seemingly balanced $\mathrm{t}(5 ; 13)(\mathrm{p} 15 ; \mathrm{q} 14)$ as the sole anomaly, heterozygous deletion of $R B 1$ but not of FOXOI and 13qter was found. The data indicate the presence of a submicroscopic deletion of the $R B 1$ locus which in its turn suggests that $R B 1$, or another gene very close, may be important in spindle cell/pleomorphic lipoma pathogenesis.

The fact is that the molecular target of chromosome 13 aberrations in spindle cell/pleomorphic lipomas, typical lipomas, cellular angiofibromas, extramammary myofibroblastoma, and angiolipoma remains unknown. Bartuma et al. (16) identified two minimal deleted regions (MDR) in $13 q 14$ for spindle cell lipoma and one for typical lipomas. These deletions were associated with down-regulated expression of several genes. Because the expression levels of $R B 1$ were not significantly reduced and because no mutations were seen by sequencing, the authors concluded that there is no decisive 
support for $R B 1$ as the main target for the13q-deletions in spindle cell lipomas (16). Instead, their data implicated miR16-1 as a potential target for the $13 q$ deletions (16). On the other hand, FISH analyses of cellular angiofibromas, extramammary myofibroblastoma, and angiolipoma detected monoallelic (and sometimes biallelic) loss of RB1 (30-32, 35, 36). Furthermore, using immunohistochemical staining for RB1, Chen et al. (37) showed that nuclear RB1 expression was deficient in all examined spindle cell lipomas, pleomorphic lipomas, and cellular angiofibromas examined by them, as well as in 17 of 19 (89\%) mammary-type myofibroblastomas.

In our series, involvement of chromosome 12 was found in $26 \%$ of the tumors. Rearrangements of the bands $12 q 13-15$ are the most common change in ordinary lipomas where they are found in two-thirds of all tumors with an abnormal karyotype (22). The translocation $\mathrm{t}(1 ; 12)(\mathrm{p} 32 ; \mathrm{q} 15)$, found in case 11 as the sole anomaly, has also been described in ordinary lipomas (29), whereas the $t(12 ; 14)(\mathrm{q} 15 ; \mathrm{q} 24)$ found in case 16 is often found in uterine leiomyomas and chondroid hamartomas (29). The target gene of the 12q13-15 rearrangements in benign connective tumors is HMGA2 (22). Our FISH experiments confirmed the involvement of $H M G A 2$ in cases 11 and 15 with 12 q15 rearrangements; neither deletion of $R B 1$ nor deletion of FOXO1 was found in these tumors.

Chromosome 16 was in the past reported as being frequently rearranged in spindle cell/pleomorphic lipomas (22). Mandahl et al. (14) found unbalanced aberrations of chromosome 16 in 7 out of 8 examined spindle cell/pleomorphic lipomas. Bartuma et al. (16) reported chromosome 16 rearrangements in 9 out of 11 tumors and Dahlén et al. (17) found similar changes in 4 of 11 tumors. In our series, only 5 out of 31 tumors had a visible aberration of chromosome 16 , and in four of them the aberration was seen together with changes of chromosome 13. In comparison, chromosomes $6,1,12$, and 11 were involved more frequently (40-20\% in decreasing order). Our data indicate that alternative genetic pathways exist for the development of spindle cell/pleomorphic lipomas, many of which are shared by other benign connective tissue tumors. However, the presence of submicroscopic deletions within $13 q 14$ or rearrangements targeting the HMGA2 locus cannot be excluded as pathogenetically important in tumors without any microscopically visible changes of chromosomes 12 and 13 .

\section{Conflicts of Interest}

The Authors declare that they have no competing interests.

\section{Acknowledgements}

This work was supported by grants from the Norwegian Radium Hospital Foundation.

\section{References}

1 Enzinger FM and Harvey DA: Spindle cell lipoma. Cancer 36: 1852-1859, 1975.

2 Angervall L, Dahl I, Kindblom LG and Save S: Spindle cell lipoma. Acta Pathol Microbiol Scand A 84: 477-487, 1976.

3 Beham A, Schmid C, Hodl S and Fletcher CD: Spindle cell and pleomorphic lipoma: an immunohistochemical study and histogenetic analysis. J Pathol 158: 219-222, 1989.

4 Bolen JW and Thorning D: Spindle-cell lipoma. A clinical, lightand electron-microscopical study. Am J Surg Pathol 5: 435-441, 1981.

5 Comunoglu N, Comunoglu C, Ekici AI, Ozkan F and Dervisoglu S: Spindle cell lipoma. Pol J Pathol 58: 7-11, 2007.

6 Domanski HA, Carlen B, Jonsson K, Mertens F and Akerman M: Distinct cytologic features of spindle cell lipoma. A cytologichistologic study with clinical, radiologic, electron microscopic, and cytogenetic correlations. Cancer 93: 381-389, 2001.

7 Fletcher CD and Martin-Bates E: Spindle cell lipoma: a clinicopathological study with some original observations. Histopathology 11: 803-817, 1987.

8 Khashper A, Zheng J, Nahal A and Discepola F: Imaging characteristics of spindle cell lipoma and its variants. Skeletal Radiol 43: 591-597, 2014.

9 Machol JA 4th, Cusic JG, O'Connor EA, Sanger JR and Matloub HS: Spindle Cell Lipoma of the Neck: Review of the Literature and Case Report. Plast Reconstr Surg Glob Open 3: e550, 2015.

10 Ide $\mathrm{H}$, Nakagawa T, Kamiyama Y, Muto S, Imamura $\mathrm{T}$ and Horie S: Spindle cell lipoma of the spermatic cord. Int J Urol 14: 1046-1047, 2007.

11 Shmookler BM and Enzinger FM: Pleomorphic lipoma: a benign tumor simulating liposarcoma. A clinicopathologic analysis of 48 cases. Cancer 47: 126-133, 1981.

12 Pitt MA, Roberts IS and Curry A: Spindle cell and pleomorphic lipoma: an ultrastructural study. Ultrastruct Pathol 19: 475-480, 1995.

13 Miettinen MM and Mandahl N: Spindle cell/pleomorphic lipoma. In: World Health Organization Classification of Tumours. Pathology and genetics of tumours of soft tissue and bone. Fletcher CDM, Bridge JA, Hogendoorn PCW, Mertens F (eds.). Lyon: IARC Press, pp. 29-30, 2013.

14 Mandahl N, Mertens F, Willén H, Rydholm A, Brosjö O and Mitelman F: A new cytogenetic subgroup in lipomas: loss of chromosome 16 material in spindle cell and pleomorphic lipomas. J Cancer Res Clin Oncol 120: 707-711, 1994.

15 Austin CD, Tiessen JR, Gopalan A, Williams JM Jr., Bangs CD, Cherry AM, Lehnert BA and Rouse RV: Spindle cell lipoma of the foot and the application of CD34 immunohistochemistry to atypical lipomatous tumors in unusual locations. Appl Immunohistochem Mol Morphol 8: 222-227, 2000.

16 Bartuma $\mathrm{H}$, Nord $\mathrm{KH}$, Macchia G, Isaksson M, Nilsson J, Domanski HA, Mandahl N and Mertens F: Gene expression and single nucleotide polymorphism array analyses of spindle cell lipomas and conventional lipomas with 13q14 deletion. Genes Chromosomes Cancer 50: 619-632, 2011.

17 Dahlén A, Debiec-Rychter M, Pedeutour F, Domanski HA, Höglund M, Bauer HC, Rydholm A, Sciot R, Mandahl N and Mertens F: Clustering of deletions on chromosome 13 in benign and low-malignant lipomatous tumors. Int J Cancer 103: 616$623,2003$. 
18 Dal Cin P, Sciot R, Polito P, Stas M, de Wever I, Cornelis A and Van den Berghe H: Lesions of 13q may occur independently of deletion of $16 \mathrm{q}$ in spindle cell/pleomorphic lipomas. Histopathology 31: 222-225, 1997.

19 Rusconi D, Valtorta E, Rodeschini O, Giardino D, Lorenzo I, Predieri B, Losa M, Larizza L and Finelli P: Combined characterization of a pituitary adenoma and a subcutaneous lipoma in a MEN1 patient with a whole gene deletion. Cancer Genet 204: 309-315, 2011.

20 Walther C, Domanski HA, von Steyern FV, Mandahl N and Mertens F: Chromosome banding analysis of cells from fineneedle aspiration biopsy samples from soft tissue and bone tumors: is it clinically meaningful? Cancer Genet 204: 203-206, 2011

21 Dumollard JM, Ranchere-Vince D, Burel F, Coindre JM, Tallini G, Ligon AH, Mayaud R, Turc-Carel C, Martin C, Mosnier JF and Pedeutour F: [Spindle cell lipoma and 13q deletion: diagnostic utility of cytogenetic analysis]. Ann Pathol 21: 303$310,2001$.

22 Heim S and Mitelman F: Cancer Cytogenetics: Chromosomal and Molecular Genetic Abberations of Tumor Cells: WileyBlackwell, Chichester, West Sussex, UK, 2015.

23 Mandahl N: Methods in solid tumour cytogenetics. In: Human cytogenetics: malignancy and acquired abnormalities. Rooney DE (eds.). New York, Oxford University Press, pp. 165-203, 2001.

24 McGowan-Jordan J, Simons A and Schmid M: ISCN 2016: An International System for Human Cytogenomic Nomenclature. Basel, Karger, 2016.

25 Panagopoulos I, Bjerkehagen B, Gorunova L, Taksdal I and Heim S: Rearrangement of chromosome bands 12q14 15 causing HMGA2-SOX5 gene fusion and HMGA2 expression in extraskeletal osteochondroma. Oncol Rep 34: 577-584, 2015.

26 Bartuma H, Panagopoulos I, Collin A, Trombetta D, Domanski HA, Mandahl N and Mertens F: Expression levels of HMGA2 in adipocytic tumors correlate with morphologic and cytogenetic subgroups. Mol Cancer 8: 36, 2009.

27 Bartuma H, Hallor KH, Panagopoulos I, Collin A, Rydholm A, Gustafson P, Bauer HC, Brosjö O, Domanski HA, Mandahl N and Mertens F: Assessment of the clinical and molecular impact of different cytogenetic subgroups in a series of 272 lipomas with abnormal karyotype. Genes Chromosomes Cancer 46: 594$606,2007$.
28 Sreekantaiah C, Leong SP, Karakousis CP, McGee DL, Rappaport WD, Villar HV, Neal D, Fleming S, Wankel A, Herrington PN, Carmona R and Sandberg AA: Cytogenetic profile of 109 lipomas. Cancer Res 51: 422-433, 1991.

29 Mitelman F, Johansson B and Mertens F: Mitelman database of chromosome aberrations and gene fusions in cancer. Available from: https://cgap.nci.nih.gov/Chromosomes/Mitelman. Last accessed February 20, 2018.

30 Panagopoulos I, Gorunova L, Bjerkehagen B, Andersen K, Lund-Iversen $\mathrm{M}$ and Heim S: Loss of chromosome 13 material in cellular angiofibromas indicates pathogenetic similarity with spindle cell lipomas. Diagn Pathol 12: 17, 2017.

31 Maggiani F, Debiec-Rychter M, Verbeeck G and Sciot R: Extramammary myofibroblastoma is genetically related to spindle cell lipoma. Virchows Arch 449: 244-247, 2006.

32 Panagopoulos I, Gorunova L, Andersen K, Lobmaier I, Bjerkehagen B and Heim S: Consistent Involvement of Chromosome 13 in Angiolipoma. Cancer Genomics Proteomics 15: 61-65, 2018.

33 Hameed M, Clarke K, Amer HZ, Mahmet K and Aisner S: Cellular angiofibroma is genetically similar to spindle cell lipoma: a case report. Cancer Genet Cytogenet 177: 131-134, 2007.

34 Maggiani F, Debiec-Rychter M, Vanbockrijck M and Sciot R: Cellular angiofibroma: another mesenchymal tumour with $13 q 14$ involvement, suggesting a link with spindle cell lipoma and (extra)mammary myofibroblastoma. Histopathology 51: 410-412, 2007.

35 Magro G, Righi A, Caltabiano R, Casorzo L and Michal M: Vulvovaginal angiomyofibroblastomas: morphologic, immunohistochemical, and fluorescence in situ hybridization analysis for deletion of 13q14 region. Hum Pathol 45: 1647-1655, 2014.

36 Flucke U, van Krieken JH and Mentzel T: Cellular angiofibroma: analysis of 25 cases emphasizing its relationship to spindle cell lipoma and mammary-type myofibroblastoma. Mod Pathol 24: 82-89, 2011.

37 Chen BJ, Marino-Enriquez A, Fletcher CD and Hornick JL: Loss of retinoblastoma protein expression in spindle cell/pleomorphic lipomas and cytogenetically related tumors: an immunohistochemical study with diagnostic implications. Am J Surg Pathol 36: 1119-1128, 2012.

Received December 29, 2017

Revised February 172018 Accepted February 21, 2018 